\title{
Histo-morphology of the Uterus and Early Placenta of the African Buffalo (Syncerus caffer) and Comparative Placentome Morphology of the African Buffalo and Cattle (Bos taurus)
}

\author{
S. Schmidt, D. Gerber, J.T. Soley, T.A. Aire and A. Boos
}

Differences exist in reproductive physiology between African buffalo (Syncerus caffer), cattle (Bos taurus) and water buffalo (Bubalus bubalis). The aim of this study was to histo-morphologically compare the anatomy of non-pregnant and pregnant uteri of buffalo and cattle. Two non-pregnant uteri and placentae of six pregnant African buffalo were used. Early placentome formation (fetal crown rump length (CRL): $2-17.5 \mathrm{~cm}$ ) in $S$. caffer and B. taurus was compared. The endometrium of buffalo uteri comprises round to ovoid, dome-shaped and gland-free caruncles. A predominantly simple columnar epithelium of non-ciliated cells covers caruncular tissue, while, additionally, ciliated cells occur in the epithelium of the intercaruncular areas and within the simple columnar or pseudostratified epithelium of the endometrial glands. During early gestation, multiple placentomes develop. Unlike the placentomes in cattle at similar CRL, buffalo placentomes do not develop a caruncular stalk. The sessile, dome-shaped buffalo placentome has simple, slightly conical villi branching less than in cattle, thus indicating different and less complex feto-maternal interdigitation than seen in the latter. A synepitheliochorial interhaemal barrier can be expected in the buffalo placenta, as the occurrence and ultrastructure of trophoblast giant cells resemble those described in cattle.

\section{Article Outline}

Introduction

Materials and methods

Tissue samples

Collection and fixation of samples from African buffalo and cattle

Processing of samples from African buffalo and cattle

Grouping of samples according to fetal size

Morphometry

Microscopic equipment and computer software

Results

The non-pregnant uterus of the African buffalo

Gross anatomy

Histology and ultrastructure

Endometrium

Surface epithelium

Uterine glands 
Early placenta of the African buffalo

Gross anatomy

Placentomes

General aspects

Villous-crypt architecture

Morphological features of the maternal component (caruncular epithelium and stroma)

Morphological features of the fetal component (chorion)

Feto-maternal contact area

Comparative placentome morphology of the African buffalo and cattle

Interplacentomal areas

Discussion

References

\section{Introduction}

The African buffalo (Syncerus caffer, S. caffer), the water buffalo (Bubalus bubalis, B. bubalis) and cattle (Bos taurus, B. taurus) represent different genera within the large family of Bovidae [1]. Morphological and molecular studies demonstrate a closer relationship between the two buffalo genera than buffalo to cattle [2] and [3]. Differences in reproductive physiology between these three bovids are reflected most obviously by the differing mean gestation lengths, being 343 days in S. caffer [4], 315 days in $B$. bubalis and 280 days in $B$. taurus [1]. This is noteworthy, considering the comparably similar calf birth weight of an approximate average of $38-40 \mathrm{~kg}$ in all three species [5], [6] and [7].

The diversity of uterine and placental morphology among mammals is remarkable, even in closely related species within an order or family. Comparative studies on placentation in ruminants include a great variety of domestic and wild species such as cattle, water buffalo, camel, deer and many antelopes [5], [8] and [9].

The bovine placenta is classified as "polycotyledonary", being composed of multiple separate placentomes with interdigitating cotyledonary villi (villous trees) within complementary caruncular crypts. Between placentomes the chorioallantois apposes the endometrium in flat to gentle folds and is referred to as either the "interplacentomal" or the "smooth chorioallantois". Placentomal gross morphology and the pattern of fetomaternal interdigitation (villous-crypt architecture) differ considerably between bovid species and change throughout the course of gestation [10] and [11]. Placentome formation with a synepitheliochorial interhaemal barrier provides placental anchoring and substance exchange between mother and fetus in most ruminants [12].

Morphological features of reproductive organs of the domesticated bovid members ( $B$. bubalis and B. taurus) are similar [1] and [8]. The only data available for S. caffer describe full term fetal membranes collected after the expulsion of the fetus from three 
African forest buffalo (S. caffer nanus), a subspecies of the African buffalo [5]. The present study was therefore designed to study gross morphology, cyto-morphology and ultrastructure of uterus and placenta of the African buffalo. A direct comparison of placentome morphology between the African buffalo and cattle was also performed and should reveal characteristics common or distinctive between the two genera.

\section{Materials and methods}

\section{Tissue samples}

\section{Collection and fixation of samples from African buffalo and cattle}

Uteri from two non-pregnant and six pregnant buffalo cows (S. caffer) were collected during disease eradication programs in the Hluhluwe/Umfolozi Game Reserve and the Kruger National Park, South Africa. Uterine samples of cattle (B. taurus) $(n=12)$ were collected during an earlier study by Boos et al. [13].

Buffalo organs/tissues were fixed via immersion and/or vascular perfusion using 2.5\% glutaraldehyde in Millonig's phosphate buffer [14]. Tissue sampling sites within the uterus included the tip and the centre of one uterine horn and the uterine body in nonpregnant animals, and the tip and the centre of the fetus-containing horn as well as the centre of the contralateral horn in pregnant animals. Each sample included both caruncular/placentomal and adjacent intercaruncular/interplacentomal areas and an attempt was made to obtain sufficient material per sample site for light microscopy (LM), scanning electron microscopy (SEM) and transmission electron microscopy (TEM). Whereas great care was taken to maintain the adhesion of feto-maternal tissues for LM and TEM, fetal membranes were carefully freed from maternal tissues for SEM and both components were rinsed thoroughly with buffered saline and were further processed separately.

\section{Processing of samples from African buffalo and cattle}

Fixed buffalo tissues were processed for LM, TEM and SEM employing appropriate standard methods. Samples for LM were stained with Haematoxylin and Eosin (HE). Additionally, Toluidine Blue (TB)-stained semi-thin sections $(0.5 \mu \mathrm{m})$ from resinembedded blocks (TEM specimens) were used when the fetal membrane was not present on HE-slides or for easier identification of fetal binucleate cells in some cases. Ultra-thin sections $(0.1 \mu \mathrm{m})$ were prepared for TEM and stained with uranyl acetate and lead citrate. SEM specimens were critical point dried in an SPI critical point drying apparatus using liquid $\mathrm{CO}_{2}$. The dried samples were mounted on aluminium stubs with carbon adhesive tabs and coated with palladium in a Polaron E 5100 sputter coater.

HE-slides of placentomal tissue from Holstein Friesian cows were obtained from the Anatomical Institute of the Vetsuisse Faculty of Zurich, Switzerland [13]. Cattle samples were investigated by LM only. 


\section{Grouping of samples according to fetal size}

All placentome samples taken from the centre of the pregnant horn were allocated into groups according to fetal CRL.

Buffalo samples were divided into group one (Buff-1): CRL 2 and $3 \mathrm{~cm}$, group two (Buff-2): CRL 8.5 and $9.5 \mathrm{~cm}$ and group three (Buff-3): CRL 15 and $17 \mathrm{~cm}$, respectively.

Domestic cow samples were divided into group one (Cow-1): CRL 2.7-3.5 cm $(n=3)$, group two (Cow-2): CRL 6.8-8.5 cm $(n=6)$ and group three (Cow-3): CRL 15-17.5 cm $(n=3)$.

Measurements on placentomal parameters were exclusively performed on HE-slides originating from above mentioned samples.

\section{Morphometry}

Epithelial height and glandular diameter were measured on HE-stained slides at 400× magnification. Ten randomly chosen areas of caruncular and intercaruncular epithelia were measured per sample. Measurements of glandular parameters (glandular diameter and epithelial height) were performed at two locations within the lamina propria: in deep endometrial tissue close to the myometrium and superficially close to the uterine lumen. Ten glandular sections were randomly chosen per location.

For comparative evaluation of villous-crypt architecture in placentomes of buffalo and cattle, measurements of cryptal lumina were performed at two different levels within each placentome: at half height and at the base of the placentome close to the maternal plate. The cryptal width was preferred to the villous diameter in order to prevent inaccuracies caused by possible shrinkage of the fragile fetal tissue.

\section{Microscopic equipment and computer software}

Light microscopic observations were carried out using a standard Olympus-Light Microscope.

A "Philips CM 10" Transmission Electron Microscope operated at $80 \mathrm{kV}$ was used for ultrastructural observations. A "Philips XL 20" Scanning Electron Microscope operated at $7 \mathrm{kV}$ was employed for examination of SEM samples. A Colorview $12^{\circledR}$ camera and the AnalySIS Prp ${ }^{\circledR}$ (version 3.2; build 757, Soft Imaging System, Münster, Germany) program were used for measurements and photo documentation. 


\section{Results}

\section{The non-pregnant uterus of the African buffalo}

\section{Gross anatomy}

The bicornuate uterus of the African buffalo consisted of parallel and curved uterine horns connected via the uterine body. The cranial portion of the uterine body was divided by a distinct septum. Caruncles appeared as slightly irregular oval prominences of the luminal surface and were arranged in two mesometrial and two antimesometrial rows along most parts of the uterine horns. Irregularities in their distribution were observed within the tips of the horns and the uterine body. The longitudinal axis of the usually oval caruncles paralleled the longitudinal axis of the uterine horns. Caruncular shapes and sizes differed slightly throughout the uterus.

\section{Histology and ultrastructure}

The uterine wall comprised three distinct tissue layers: a tunica mucosa (endometrium), tunica muscularis (myometrium) and tunica serosa (perimetrium). Only the endometrium is described in this study.

\section{Endometrium}

The endometrium consisted of the lamina epithelialis (surface epithelium) and the lamina propria mucosae. Dome-shaped thickenings of the lamina propria (LP) represented caruncles, which were separated from one another by thinner, intercaruncular areas. The LP was arranged in two layers: a sub-epithelial cellular zone and a deeper vascular zone lying immediately adjacent to the tunica muscularis. Simple, branched and coiled tubular glands were visible throughout the entire LP. They were, however, mostly restricted to slightly deeper layers below the caruncles as the caruncular tissue proper was devoid of glands. The caruncular vascular zone comprised numerous thick-walled, muscular arteries and veins, which were continuous with the vascular plexus of the myometrium. Vessel diameters decreased towards the luminal surface of the uterus, forming arterioles and venules which terminated in a capillary network within the sub-epithelial cellular zone. The latter zone displayed a broad band of densely packed fibrocytes, embedded in a sparse extracellular matrix. The LP of intercaruncular areas was similar in appearance to that in caruncular areas but vascular supply was less extensively developed. Glandular tissue was most abundant in the deeper layers of the LP (average glandular diameter $22.4 \mu \mathrm{m}$ ), less numerous within more superficial regions (average glandular diameter $32.7 \mu \mathrm{m}$ ) and relatively few ducts opened into the uterine lumen. Lymphocytes were scattered throughout the LP or formed small lymphoid follicles, predominately in the sub-epithelial region. Macrophages were scattered throughout the LP or concentrated in the vicinity of lymph follicles. 


\section{Surface epithelium}

A simple columnar epithelium covered most surface areas examined although a simple cuboidal or pseudostratified type was sometimes observed. The epithelium and underlying LP often displayed a wavy appearance in the caruncular areas, resulting in a series of ridges and intervening depressions. This phenomenon was obvious by both LM (Figure 1a) and SEM (Figure 1b,c). Epithelial height averaged $26.0 \mu \mathrm{m}$ in caruncular and $13.8 \mu \mathrm{m}$ in intercaruncular areas. Nuclei were generally oval in shape and basally situated. The ratio of cell height to nucleus height was 1.8:1 and 1.5:1 in caruncular and intercaruncular areas, respectively. Intraepithelial lymphocytes were randomly distributed throughout the epithelium (Figure 1a). The average ratio of epithelial cells to intraepithelial lymphocytes per $111 \mu \mathrm{m}$ of epithelium was 6.5:1 in caruncular and 7.7:1 in intercaruncular areas.
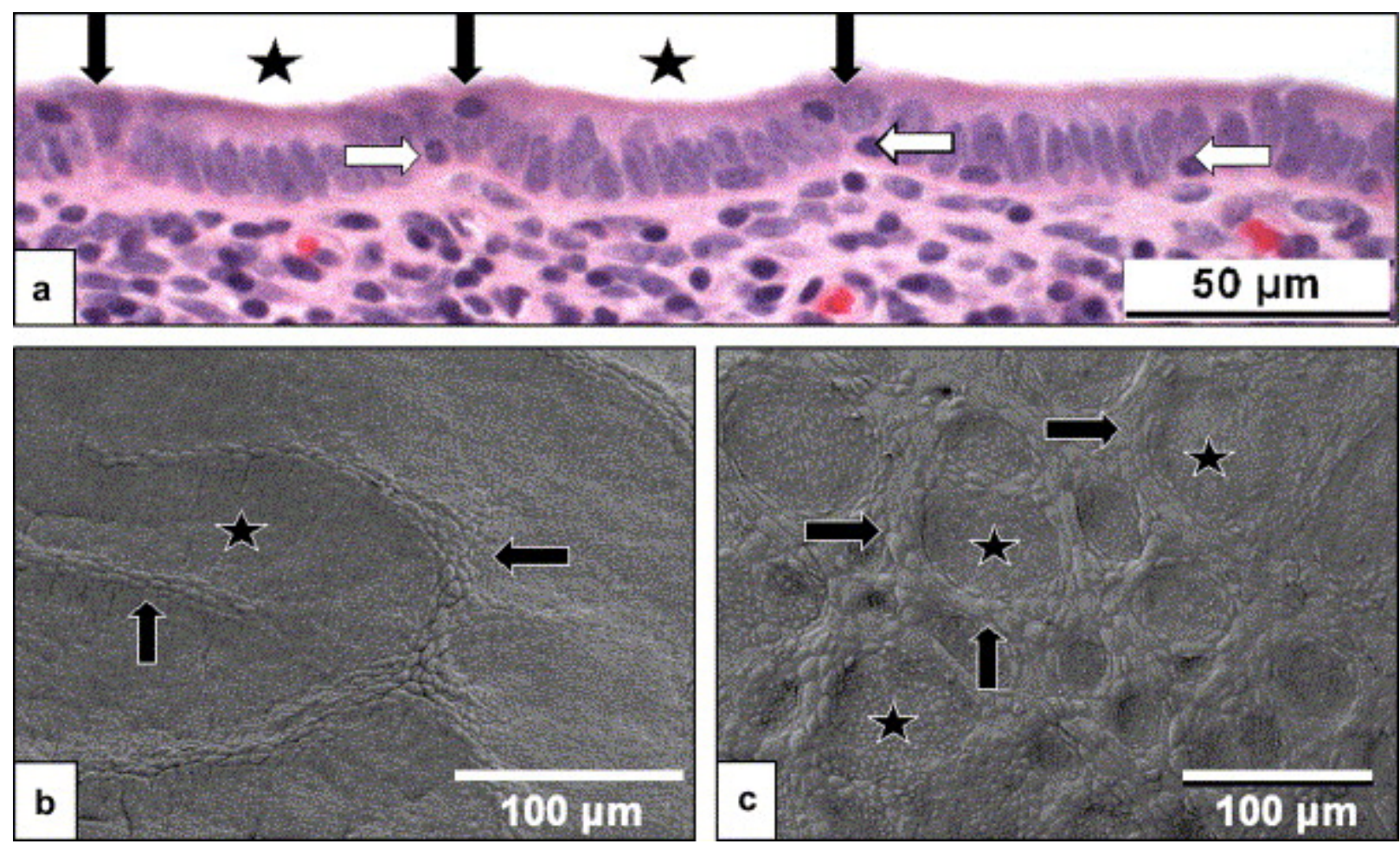

Figure 1. LM (a) and SEM (b and c) micrographs of caruncular surfaces of the African buffalo endometrium. (a) The simple columnar surface epithelium and adjacent lamina propria exhibit a distinct wavy appearance. Ridges (black arrows), tissue depressions (stars), intraepithelial lymphocytes (white arrows). (b and c) Bulging epithelial cells form loosely connected (b) or circular (c) cellular ridges (black arrows), surrounding shallow depressions (stars) of varying diameters. 
On SEM, endometrial caruncles were clearly identifiable as round to ovoid, elevated areas devoid of gland openings (Figure 2). Cellular ridges gave the caruncular surface a net-like appearance (Figure 1b,c). Ridges consisted of large, bulging, elongated cells, distinctly different from surrounding flat, hexagonal epithelial cells. The latter measured approximately $5 \mu \mathrm{m}$ in diameter whereas ridge cells were approximately $13 \mu \mathrm{m}$ in length and $4 \mu \mathrm{m}$ in width, although lengths of up to $22 \mu \mathrm{m}$ were also recorded. Ridges were frequently interconnected, incompletely surrounding shallow hollows of normal cells in one animal (Figure 1b) and completely encircling variably sized depressions $(30-100 \mu \mathrm{m}$ inner diameter) in the other animal (Figure 1c).

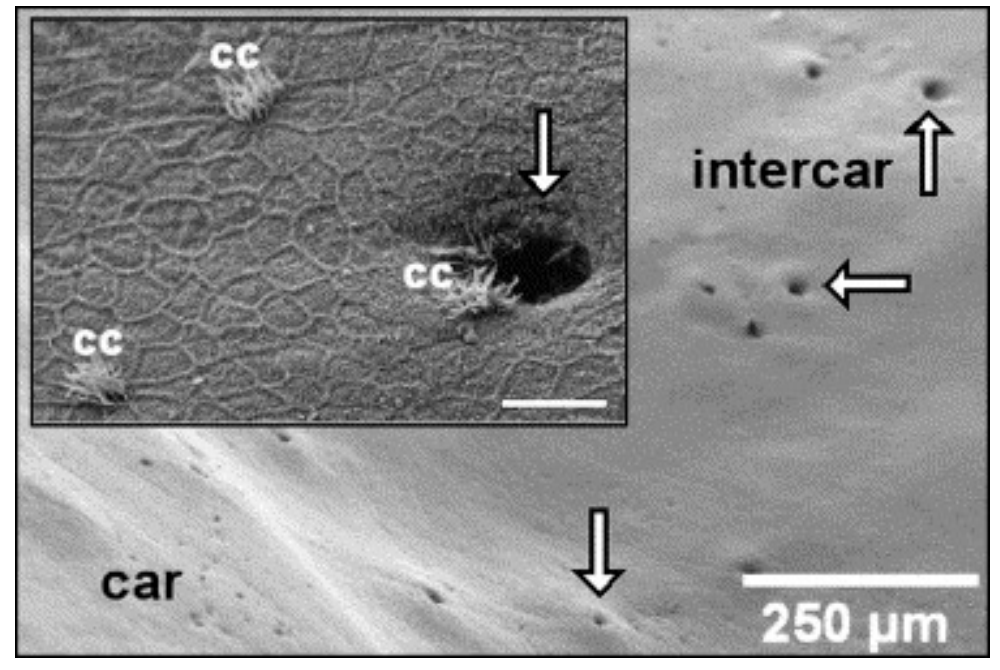

Figure 2. SEM micrograph of caruncular (car) and intercaruncular (intercar) surfaces of the buffalo endometrium. Gland openings (arrows) are restricted to the intercaruncular surface. Inset: a single gland opening (arrow) surrounded by non-ciliated and ciliated cells (cc) (inset: bar $=10 \mu \mathrm{m}$ ).

Intercaruncular areas displayed a relatively smooth surface with numerous, unevenly distributed round to ovoid gland openings (Figure 2). In one animal large numbers of ciliated cells were randomly distributed throughout intercaruncular areas, whereas in the other they were restricted to the vicinity of gland openings (inset, Figure 2).

Surface epithelial cell ultrastructure was similar in both caruncular and intercaruncular areas. Light and dark staining columnar cells rested on a straight or slightly undulating basement membrane (Figure 3a). The apical surface displayed numerous, approximately $0.7 \mu \mathrm{m}$ long microvilli (Figure 3a,b). Cilia were exclusively observed on some light cells in the intercaruncular areas. Lateral cell membranes of adjacent cells exhibited distinct junctional complexes apically (Figure 3a) and lateral infoldings along their course towards the basement membrane. The basally located nuclei were ovoid in shape but often indented (Figure 3a). Cytoplasmic organelles occurred in moderate numbers. Variably shaped mitochondria as well as concentric lamellar bodies and glycogen $(\alpha$ and 
$\beta$ types) were mainly situated in the supranuclear region. Occasional giant mitochondria were also encountered. Profiles of rough and vesicular smooth endoplasmic reticulum (rER, sER) as well as moderate numbers of free ribosomes were found throughout the cytoplasm. Profiles of the Golgi apparatus (GA) were sparse. Multivesicular bodies, dense bodies, vesicles and lysosome-like structures were occasionally observed. Intraepithelial lymphocytes with round, densely stained nuclei were visible at various levels within the epithelium. Intraepithelial mast cells and macrophages occasionally occurred.
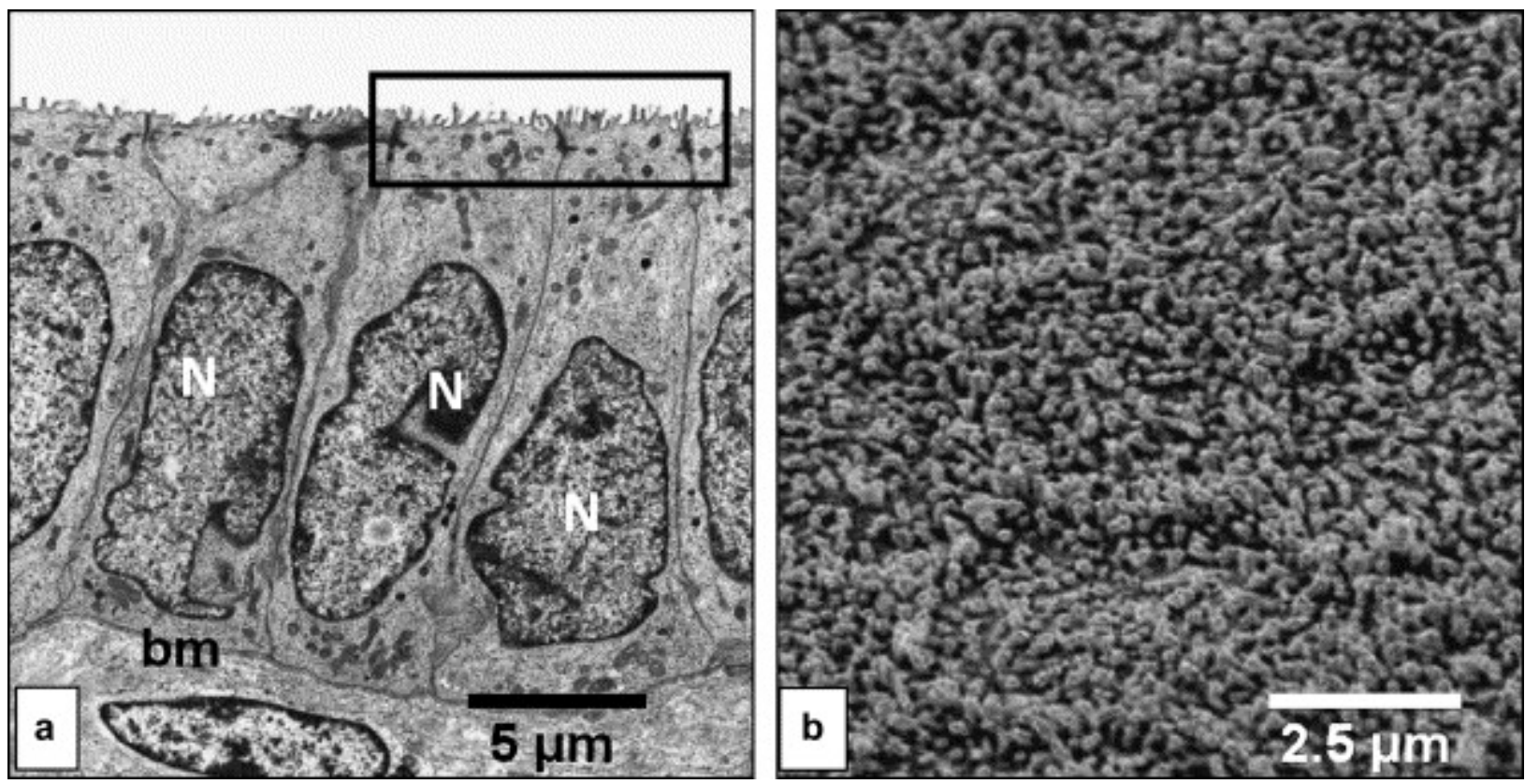

Figure 3. (Buffalo) TEM (a) and SEM (b) micrographs of caruncular surface epithelial cells. (a) Columnar epithelial cells rest on a distinct basement membrane (bm) and contain basally situated nuclei $(\mathrm{N})$ of irregular, ovoid shape. Note junctional complexes and microvilli (rectangle). (b) The hexagonal shape of the luminal surface of epithelial cells is slightly masked by the presence of numerous microvilli.

\section{Uterine glands}

In glandular profiles observed near the myometrium the average height of the simple columnar epithelium was $8.3 \mu \mathrm{m}$ compared to $11 \mu \mathrm{m}$ in profiles encountered in more superficial regions of the LP. Some glandular sections were lined with a pseudostratified epithelium and intraepithelial lymphocytes commonly occurred. Luminal content was sparse and glandular ducts opened vertically or at an oblique angle onto the luminal surface. 
The main difference between the surface and glandular epithelia was the occurrence of abundant ciliated cells in the glandular epithelium. Within the glandular epithelium, nonciliated cells had more secretory vesicles beneath the luminal surface than did the ciliated cells. Cell ultrastructure did not differ significantly from that of surface epithelial cells but the number, size and distribution of glycogen fields were much greater and widespread in glandular than in surface epithelial cells. Concentric lamellar bodies and giant mitochondria were never observed. The apex of the cells often bulged into the glandular lumen and some of these protrusions were constricted at their base. Adjacent cells were connected via apical junctional complexes and indistinct lateral infoldings.

\section{Early placenta of the African buffalo}

\section{Gross anatomy}

The buffalo placenta was classified as polycotyledonary. Placentomes were round, ovoid or irregular in shape and were arranged in four rows along the centre of both uterine horns. Their distribution pattern became more irregular towards the tip of the horns and within the uterine body. The longitudinal axis of ovoid placentomes was orientated perpendicular to the longitudinal axis of the uterine horns. Most advanced placentomes were located in the periembryonic region (centre of pregnant uterine horn).

Fetal membranes had spread throughout both uterine horns in all specimens examined. However, the fragile connection between fetal and maternal tissues was sometimes lost during sampling and processing of samples from earliest gestational stages (Buff-1).

\section{Placentomes}

\section{General aspects}

Generally, placentomes manifested as sessile (non-stalked), dome-shaped endometrial caruncles, in contact with the corresponding fetal cotyledons. However, in Buff-1, young placentomes originating from the tip of the pregnant and the centre of the non-pregnant uterine horn exhibited an undulating surface as the only visible difference to caruncles described in non-pregnant animals, as obvious crypt-villous formation had not yet started.

More advanced placentomes (Buff-1 centre of pregnant horn, Buff-2 and Buff-3) consisted of maternal tissue comprising a straight placentomal basal plate (maternal plate) and vertically orientated cryptal septae, which subdivided the placentome into compartments (primary crypts, Figure 4, S. caffer). The fetal tissue formed a concave chorionic plate (fetal plate), which covered the corresponding maternal tissue like a hat. Chorionic villi at various stages of development projected from the chorionic plate into the maternal crypts and followed a parallel course towards the maternal plate where they ended in a straight line. Villi were longest in the centre and shorter towards the periphery of the placentome, giving the latter a convex appearance (Figure 4, S. caffer). The tips of 
the primary chorionic villi were frequently observed to divide into two or more branches close to the maternal plate.
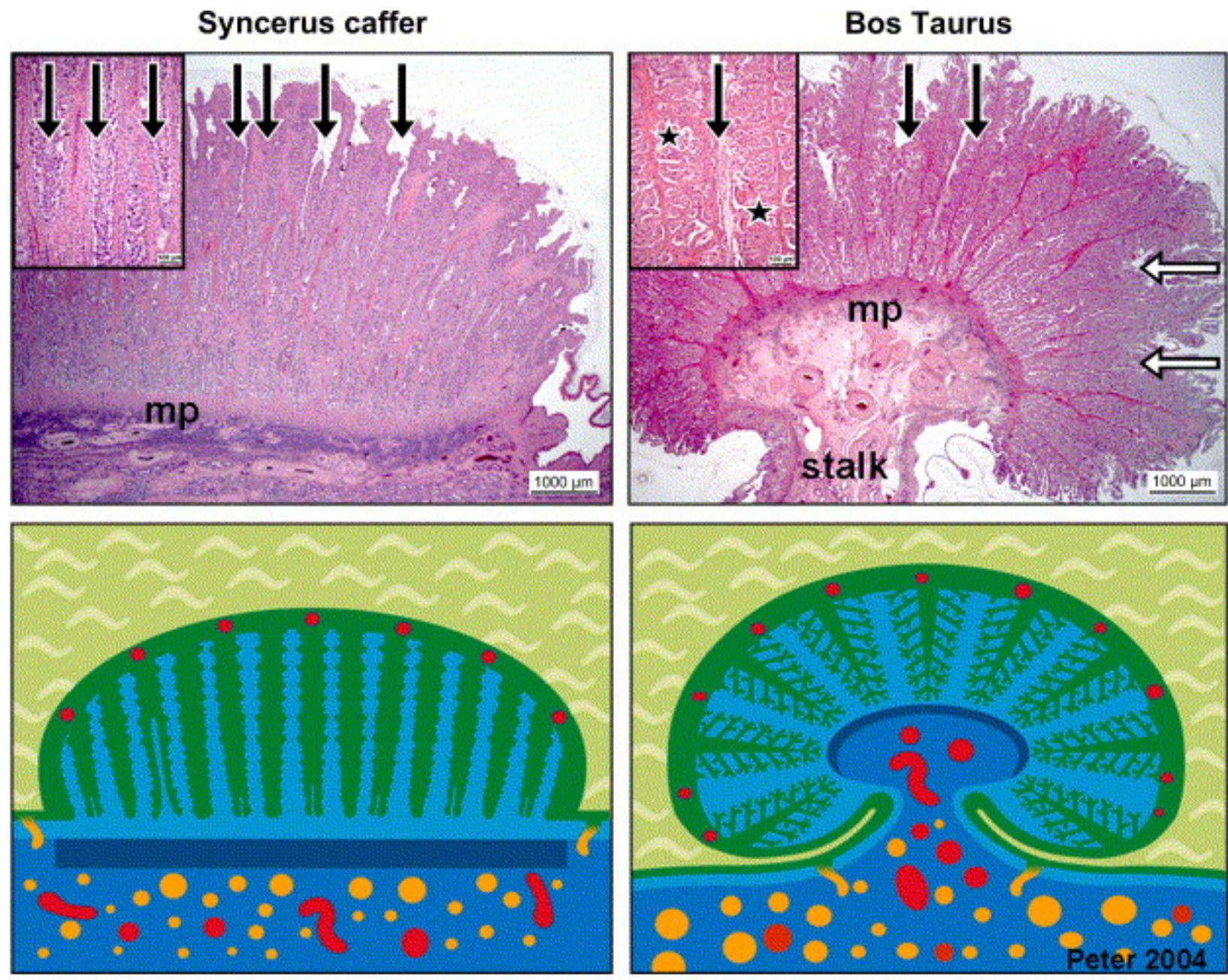

Dense cell layer

Chorionic plate and chorionic villi

Mat. plate and cryptal walls

Endometrial glands

Blood vessels

Figure 4. Light micrographs and graphic illustrations of buffalo (S. caffer) and cattle (B. taurus) placentomes (CRL $\approx 9 \mathrm{~cm})$. The buffalo placentome is dome-shaped with a straight maternal plate ( $\mathrm{mp}$ ) and a distinct, cell-rich basal layer. Note the continuous occurrence of glandular tissue close to the maternal plate. The stem villi (arrows) project from the chorionic plate in an almost parallel manner. Inset: stem villi (arrows) within caruncular crypts. The villous surface demonstrates a slightly uneven course but no secondary branching. The cattle placentome is convex and mushroom shaped due to stalk formation. The maternal plate is curved and the cell-rich layer poorly developed.

Glandular tissue is restricted to deep areas of the lamina propria. Stem villi (arrows) project at an approximate right angle from the chorionic plate and follow a vertical course in the centre (black arrows) and an approximately horizontal course (white arrow) at the 
placentome periphery. Inset: stem villus (arrow) projecting secondary and tertiary branches (stars).

\section{Villous-crypt architecture}

Except for placentomes in very early stages of development, all placentomes displayed varying degrees of feto-maternal interdigitation of chorionic villi within corresponding caruncular crypts. "Young" chorionic villi (stem villi) on separated cotyledonary tissue from Buff-1 (centre of pregnant horn) appeared as simple, finger-like projections from the chorionic plate when viewed by SEM (Figure 5a,b). Most villi originated as a group of four to six individuals from a common chorionic base. The distance between separate villous-groups corresponded to approximately four times the diameter of a single villus (Figure 5b). Some villi divided into two or more villi at an acute angle shortly after their origin or did so close to their distal end (Figure 5a). The villous surface was smooth, as lateral branches were lacking. Corresponding crypt openings appeared as round to ovoid structures at the caruncular surface (Figure 5a). Some openings occurred as single primary depressions of the surface whereas the majority manifested as primary depressions with additional smaller, round openings just below the luminal surface. Broad endometrial crests (arcade areas) separated individual crypt openings (Figure 5a). Crypt walls appeared smooth when viewed by LM, as they were not yet indented by lateral villous branching. Longest crypts in the centre of the largest placentome reached a mean length of $390 \mu \mathrm{m}$.
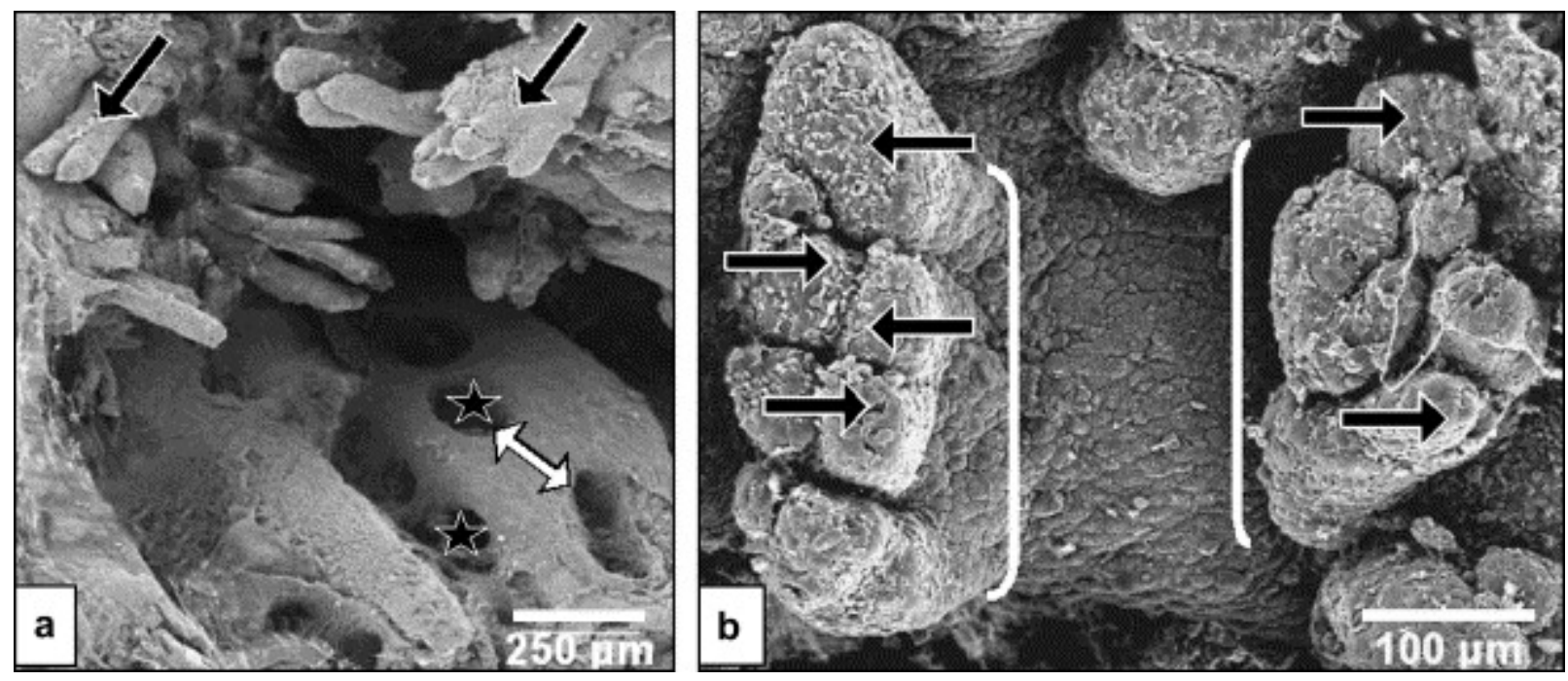

Figure 5. (a) SEM micrograph of a buffalo placentome $(C R L=3 \mathrm{~cm})$ following partial separation of caruncular and cotyledonary tissues. Note the crypt openings (stars) on the caruncular surface, intervening endometrial crests (white arrow) and corresponding finger-like, chorionic stem villi (black arrows). (b) SEM micrograph of the separated 
chorionic surface in the same animal. Note the origin of stem villi (arrows) from a common base (brackets) on the chorionic plate.

In Buff-2, however, stem villi within their corresponding crypts had increased in length, extending close to the maternal plate in a vertical fashion (Figure 4, S. caffer) and reaching an approximate length of $3.2 \mathrm{~mm}$ within the largest placentomes. Most primary villi originated from a common base at the chorionic plate and frequently divided longitudinally into two or more parallel, vertical stem villi. The basal third of most stem villi possessed short, bulbous, lateral branches (buds, secondary villi) which emerged at approximately right angles, and conferred a "rough" surface on the stem villus. Distal parts of stem villi usually lacked these lateral structures and therefore displayed "smooth" surfaces. All stem villi were somewhat thinner towards their distal ends, thus demonstrating a slender, slightly conical shape. The majority of stem villi terminated in two or more villous tips. Walls of caruncular crypts corresponded intimately with villous contours.

Primary villi in Buff-3 (Figure 6) resembled the slender, slightly conical villi described in Buff-2 but were markedly longer (approximately $7.5 \mathrm{~mm}$ ) and demonstrated distinct surface corrugations and a few remaining smooth areas (Figure 6). Secondary villi could be clearly demonstrated by SEM and appeared as semicircular or elongated buds along the stem villous surface (Figure 6). Divisions of stem villi into two or more villi of equal order could also be observed. On the caruncular surface, crypt openings were ovoid or irregular in shape and frequently revealed secondary openings immediately beneath the initial crypt opening. Less maternal arcade tissue was present due to the larger crypt openings when compared to Buff-1 specimens.

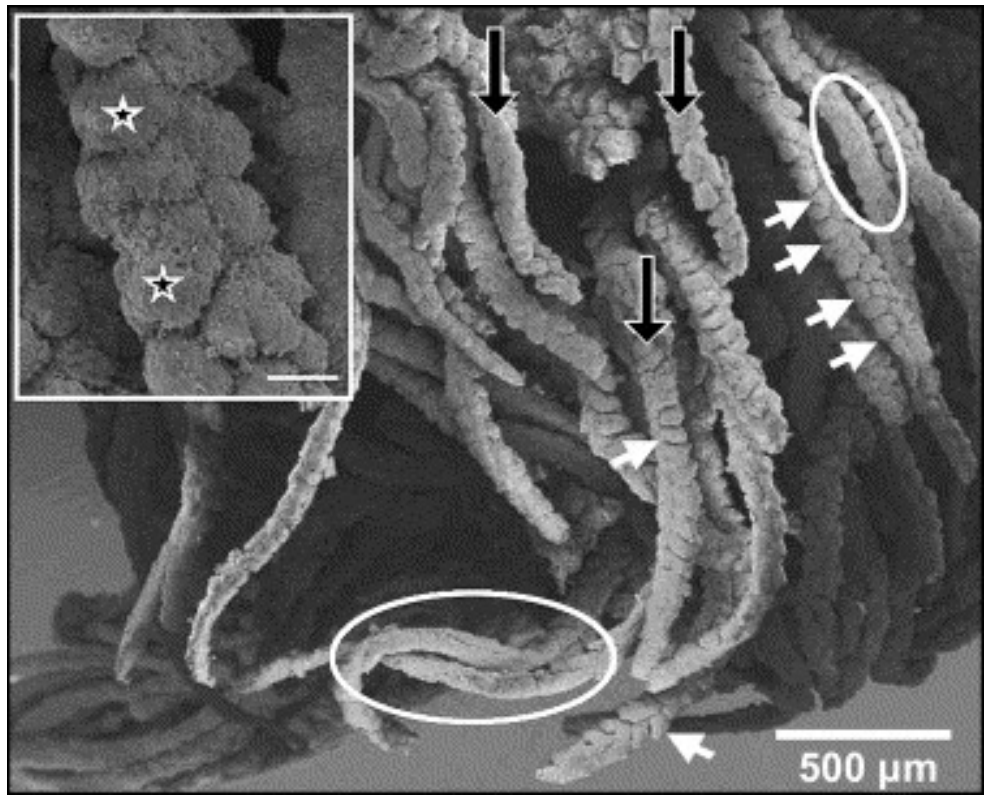


Figure 6. (Buffalo, $\mathrm{CRL}=17 \mathrm{~cm}$ ) SEM micrograph of chorionic stem villi (black arrows) demonstrating secondary projections (white arrows) and occasional smooth areas (circles). Inset: close-up of a stem villus projecting secondary, bulbous villi (stars) (bar $=50 \mu \mathrm{m})$.

\section{Morphological features of the maternal component (caruncular epithelium and stroma)}

The caruncular and crypt wall epithelia were generally cuboidal in nature, displaying an average height of $10.5 \mu \mathrm{m}$ and comprised two cell types: predominantly uninucleate epithelial cells (UEC) and fewer multinucleate cells (MNC). Flat epithelial cells lined some arcade areas, between crypt openings, and occasionally the basal parts of caruncular crypts. In placentomes from the non-pregnant horn of Buff-1, localised complete stripping of the surface epithelium often resulted in exposure of the basement membrane. Shape of the basally situated nuclei of UEC was round/ovoid in tall whereas flat in low epithelial cells. Lateral cell borders between adjacent UEC were indistinct and lateral folding of adjacent membranes was rare. Microvilli were short, sparse or even absent in specimens from Buff-1 and Buff-2 whereas they were longer and more numerous in Buff-3 specimens. Cytoplasmic organelles/inclusions present were round to ovoid mitochondria, rER, free ribosomes, poly-ribosomes and variably sized lipid droplets. No giant mitochondria or glycogen fields were observed. Typical MNC were much larger than UEC, ovoid or irregular in shape and were generally surrounded by UEC. Most MNC contained two or three nuclei but up to 10 nuclei per cell were occasionally observed. The most obvious cytoplasmic feature was the varying number of membrane bound granules, similar to those observed in fetal binucleate cells (trophoblast giant cells, TGC, see below). Granules were mainly located in the basal cytoplasm whereas small ovoid or irregular shaped structures resembling degenerated or swollen mitochondria were found as the only obvious organelles in supranuclear areas. Lipid droplets occasionally occurred and few microvilli projected from the luminal surface of each MNC. Moderate numbers of mitotic figures were observed throughout the crypt epithelium whereas intraepithelial lymphocytes were absent. Sub-epithelial capillaries were numerous and frequently indented the epithelial basement membrane.

In earliest stages of placentomal development (prior to crypt formation) the gland-free caruncular stroma consisted of a deeper, dark, cellular layer bordering the endometrial vascular zone and a more superficial, lighter, predominately fibrous layer extending to the basement membrane of the surface epithelium. In later stages of placentomal development (Figure 4, S. caffer), crypt formation exclusively occurred within that upper layer which formed the supporting tissue of crypt walls. This tissue displayed occasional lymphocytes, centrally positioned, thin-walled arteries and veins, more peripherally positioned arterioles and venules and a well-developed sub-epithelial capillary network. The base of the crypts lay adjacent to a thin, light, fibrous band, which was always supported by a distinct, dense cellular band, separating the placentomal tissue proper from the vascular sub-placentomal endometrium containing the uterine glands (Figure 4, 
S. caffer). The distinctness of the cell-rich layer diminished slightly as gestation proceeded. Glandular profiles occurred within the entire sub-placentomal zone in all specimens examined.

\section{Morphological features of the fetal component (chorion)}

Generally, the chorion consisted of an inner layer of vascularized mesenchyme and the outer chorionic epithelium (trophoblast). The fine meshwork of mesenchymal tissue formed the cores of chorionic villi. Blood vessels originating from large vessels within the chorionic plate coursed along the centre of each stem villus. Numerous arterioles and venules as well as a rich capillary network were apparent at the periphery of the stem villus and in secondary branches thereof.

The pseudostratified trophoblast epithelium contained two different cell types: mononuclear trophoblast epithelial cells (MonoTC) and trophoblast giant cells (TGC). Mononuclear trophoblast cells predominated and occurred as slightly irregular, cuboidal cells with a height ranging between 22 and $33 \mu \mathrm{m}$. Round to ovoid mitochondria were mainly located in the supranuclear cytoplasm. Other cytoplasmic organelles included: lysosomes at various developmental stages (especially in columnar cells abutting arcade areas, Figure 7a), lipid droplets, occasional multivesicular bodies, thin strands of rER and a poorly developed Golgi apparatus. Generally, all MonoTC displayed microvilli but these were often unevenly distributed over the apical surface during early gestation. Some cells demonstrated variably shaped apical cytoplasmic protrusions, which entirely lacked microvilli. Large numbers of small vesicles also occupied the apical cytoplasm. Neighbouring cuboidal MonoTC were connected via finger-like interdigitations of the lateral membranes and frequently possessed microvilli over a short distance along their apico-lateral cell membranes. Neighbouring tall columnar cells of some arcade areas displayed interdigitating microvilli along approximately two-thirds of the apico-lateral membranes and only the basal parts of adjacent cells were connected via junctional complexes (Figure 7a). 

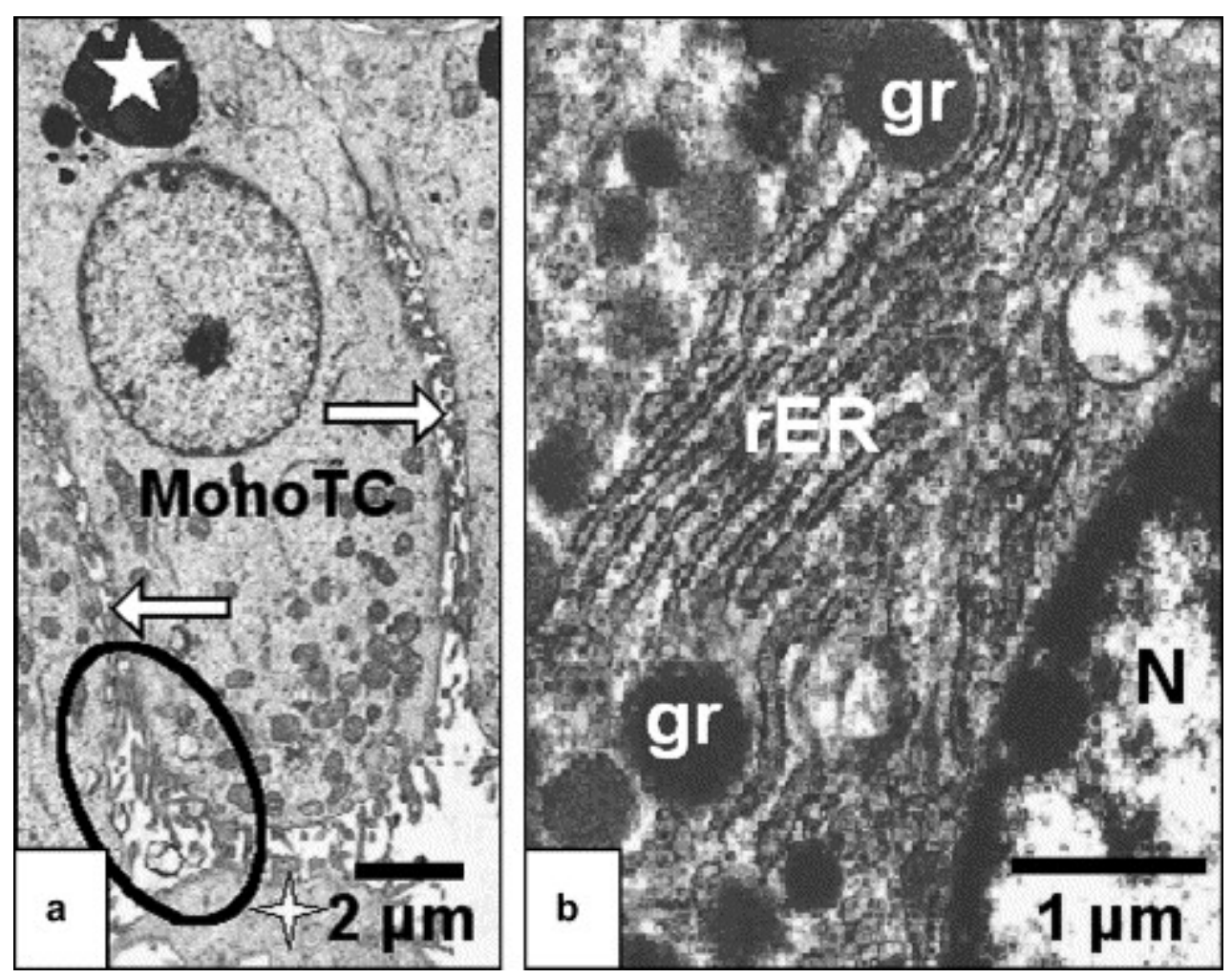

Figure 7. (Buffalo) TEM micrographs of (a) columnar mononuclear trophoblast cells (MonoTC) abutting arcade areas. A single uterine epithelial cell (cross) is seen forming a typical triangular space (circle) between itself and two adjacent MonoTC. Note the interdigitating microvilli along two-thirds of the lateral cell membranes (arrows) and the large lysosomal structure (star) within the basal cytoplasm of MonoTC. (b) Part of a trophoblast giant cell. The nucleus $(\mathrm{N})$, cytoplasmic granules (gr) and rough endoplasmic reticulum (rER) are clearly visible.

Trophoblast giant cells (TGC) were typically ovoid in shape and their cytoplasm stained more intensely than that of MonoTC in both LM and TEM sections. Trophoblast giant cells occurred at various levels within the epithelium and were larger $(22-37 \mu \mathrm{m}$ long and 17-24 $\mu \mathrm{m}$ wide) than surrounding MonoTC, to which they were connected via desmosome-like structures. Usually two nuclei were present in a single TGC but only one nucleus per cell was commonly visible due to the plane of section. Numerous cytoplasmic granules were characteristic for TGC (Figure 7b). These were membrane bound structures, round to ovoid in shape, grainy and of variable electron density. Some granules contained a few microvesicles. Granule size and distribution differed markedly within and between cells, depending on the cell's position taken up within the epithelium. Cells closest to the fetal basement membrane were sparsely granulated or devoid of granules whereas granule numbers increased in cells situated closer to the microvillar junction. Trophoblast giant cells intermediately positioned between the trophoblast and the uterine surface epithelium, contained granules in that part of the cytoplasm which was 
situated within the maternal epithelium (data not shown). One to several lipid inclusions were apparent in some cells, rough ER occurred in varying amounts and forms, mitochondria were small and round to ovoid in shape and the Golgi apparatus was difficult to identify.

\section{Feto-maternal contact area}

Contact areas between the trophoblast and uterine epithelium were observed throughout the uterus, but the formation of a distinct microvillar junction (MVJ) was rare in Buff-1 and Buff- 2 due to the sparse amount of microvilli on caruncular epithelial cells. Trophoblast microvilli were frequently in contact with the non-microvillous maternal epithelial surface. Due to the uneven distribution of microvilli on MonoTC, feto-maternal contact sometimes occurred between non-microvillous parts of both trophoblast and uterine epithelial cells (data not shown). Where an MVJ was established, dark amorphous material occurred between the microvilli. A thin space, which sometimes occurred between trophoblast and caruncular surface epithelium, contained cellular debris of varying density. A distinct MVJ was established on Buff-3 specimens. Due to the characteristic bulge-like apex of the MonoTC, triangular gaps were formed between adjacent MonoTC and opposing caruncular epithelial cells. The gaps contained microvilli emerging from the MonoTC (Figure 7a).

\section{Comparative placentome morphology of the African buffalo and cattle}

During early gestation (Buff-1/Cow-1) placentomes appeared similar. Differences mainly involved mean crypt lengths at the centre of the placentomes, which were $390 \mu \mathrm{m}$ and $735 \mu \mathrm{m}$ in buffalo and cattle, respectively. Crypt walls were slightly uneven in cattle compared to entirely smooth walls in buffalo placentomes.

Divergent placentome development became apparent in Buff-2/Cow-2 and Buff-3/Cow-3 specimens (Figure 4). While buffalo placentomes remained dome-shaped (nonpedunculated) in all three groups, cattle placentomes presented two morphologically different types of placentomes (non-pedunculated and pedunculated) in Cow-2. The nonpedunculated type resembled placentomes described in the buffalo (see General aspects) but villous branching was more elaborate and villous units were generally wider throughout their length in Cow-2. The pedunculated type demonstrated a characteristic mushroom-shape with a distinct caruncular stalk and a convex basal plate and was found in Cow-2 (some placentomes) and Cow-3 (all placentomes) (Figure 4, B. taurus). Cotyledonary villous architecture reflected the morphological differences in respect of the organization and shape of stem villi and corresponding branches (villous tree). In pedunculated placentomes (Figure 4, B. taurus), stem villi radiated at approximately right angles from the chorionic plate towards the tip of the narrow caruncular stalk. Therefore, villous trees in the centre of the placentomes occupied strictly vertically orientated main crypts, whereas those within crypts at the placentomal periphery were aligned horizontally, thus overlapping the interplacentomal endometrium immediately lateral to the caruncular stalk. Each stem villus displayed distinct lateral branches along its length. These secondary villi projected at approximately right angles from the stem villus, were 
elongated and sometimes split further at their distal ends into tertiary (terminal) villi. Due to the progressive proximo-distal decrease in length of secondary villi, each villous unit was triangular/conical in shape and resembled a Christmas tree. The corresponding caruncular crypt wall entirely surrounded each villous unit, resulting in a distinct compartmentalization of the placentomes.

The densely stained, cell-rich layer of the basal plate described in buffalo placentomes was less intensely developed in Cow-1 and Cow-2 (Figure 4, B. taurus) and hardly recognizable in specimens from Cow-3. Glandular profiles were restricted to the base of the caruncular stalk or totally absent in cattle specimens, whereas glands occurred beneath the entire placentome in the buffalo (Figure 4, S. caffer).

Measurements of the range and mean crypt luminal diameters $(\mu \mathrm{m})$ in African buffalo and cattle placentomes are demonstrated in Table 1.

\section{Table 1.}

Range and mean cryptal luminal diameters $(\mu \mathrm{m})$ performed at two different levels of nonpedunculated (non-ped) and pedunculated (ped) buffalo and cattle placentomes; measurements were performed at the placentome centre (half height) and the placentome base (close to maternal plate)

\begin{tabular}{|c|c|c|c|c|c|}
\hline $\begin{array}{l}\text { Measurement level of cryptal luminal } \\
\text { diameter }\end{array}$ & Buff-2 & Buff-3 & $\begin{array}{l}\text { Cow- } \\
2\end{array}$ & $\begin{array}{l}\text { Cow- } \\
2\end{array}$ & $\begin{array}{l}\text { Cow- } \\
3\end{array}$ \\
\hline & $\begin{array}{l}\text { Non- } \\
\text { ped }\end{array}$ & $\begin{array}{l}\text { Non- } \\
\text { ped }\end{array}$ & $\begin{array}{l}\text { Non- } \\
\text { ped }\end{array}$ & Ped & Ped \\
\hline \multirow[t]{2}{*}{ Centre of placentome } & $\begin{array}{l}120- \\
238\end{array}$ & $\begin{array}{l}250- \\
410\end{array}$ & $\begin{array}{l}265- \\
390\end{array}$ & $\begin{array}{l}515- \\
770\end{array}$ & $\begin{array}{l}784- \\
822\end{array}$ \\
\hline & 173 & 334 & 362 & 692 & 800 \\
\hline \multirow[t]{2}{*}{$\begin{array}{l}\text { Base of placentome (crypts containing }>1 \\
\text { villous tip) }\end{array}$} & $\begin{array}{l}67- \\
155\end{array}$ & $\begin{array}{l}165- \\
261\end{array}$ & $\begin{array}{l}110- \\
282\end{array}$ & $\begin{array}{l}108- \\
251\end{array}$ & $\begin{array}{l}154- \\
206\end{array}$ \\
\hline & 100 & 199 & 150 & 156 & 176 \\
\hline \multirow[t]{2}{*}{$\begin{array}{l}\text { Base of placentome (crypts containing } \\
\text { single villous tip) }\end{array}$} & $31-70$ & $\begin{array}{l}55- \\
161\end{array}$ & $\begin{array}{l}56- \\
104\end{array}$ & $\begin{array}{l}31- \\
104\end{array}$ & $\begin{array}{l}60- \\
151\end{array}$ \\
\hline & 55 & 98 & 80 & 61 & 102 \\
\hline
\end{tabular}

Cryptal lumen at the basal placentome were further divided into crypts containing more than one and those containing a single villous tip. Buff- 2 and Buff-3 demonstrated nonpedunculated placentomes only. Cow-2 had both, pedunculated and non-pedunculated placentomes, while Cow-3 had pedunculated placentomes only. 


\section{Interplacentomal areas}

In S. caffer, the surface of the interplacentomal endometrium varied from smooth to slightly or intensely folded throughout the uterus. The uterine surface epithelium generally made intimate contact with the trophoblast epithelium and both epithelia contained similar cell types to those observed in placentomal areas. In the material examined, no intraepithelial lymphocytes were observed. Due to the loss of parts of the uterine epithelium, however, the presence of these cells cannot be excluded. The dense, cell-rich layer described beneath placentomes did not continue into interplacentomal areas. Sub-epithelial lymph follicles were occasionally observed.

Glandular profiles occurred within the lamina propria of interplacentomal areas as well as beneath placentomal tissue. Gland diameters $($ mean $=37 \mu \mathrm{m})$ in the deep portion of the lamina propria were similar in Buff-1, Buff-2 and Buff- 3 and the simple, columnar epithelium measured $13.5 \mu \mathrm{m}$ (Buff-1 and Buff-2) and $11.3 \mu \mathrm{m}$ (Buff-3) in height, respectively. Mean glandular diameters within the superficial lamina propria, where less glandular profiles occurred, were $65.0 \mu \mathrm{m}$ in Buff-1 and Buff-2 and $60.2 \mu \mathrm{m}$ in Buff-3, with a corresponding epithelial height of $23.0 \mu \mathrm{m}, 20.0 \mu \mathrm{m}$ and $18.3 \mu \mathrm{m}$, respectively. Gland openings were rare when compared to the high number of glandular profiles observed. In Buff-1 and Buff-2, gland openings were lined by a regular, simple columnar epithelium, whereas in some openings of Buff-3 epithelial cells were large, variously shaped and pale. Ciliated and non-ciliated glandular epithelial cells generally resembled those described in the endometrium of cycling buffalo but glycogen fields were absent. An interesting feature was the occurrence of small, narrow infoldings within the basal cytoplasm of ciliated and non-ciliated cells, similar to infoldings described in epithelial cells lining the renal proximal tubuli (Figure 8). 


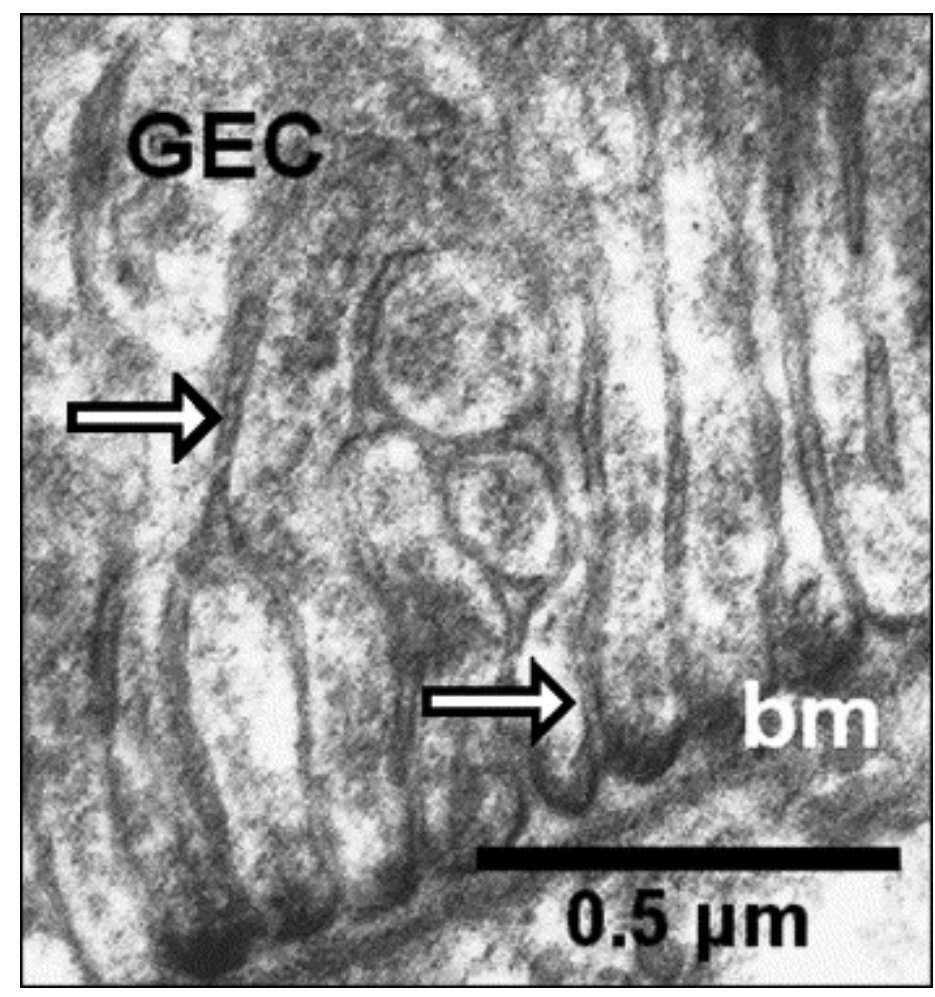

Figure 8. (Buffalo) TEM micrograph of the basal cytoplasm of a glandular epithelial cell (GEC). Note the underlying basement membrane (bm) and the numerous infoldings of the plasma membrane (arrows).

High columnar trophoblast epithelial cells, similar to cells lying against arcade areas (placentomal areas), occurred at two specific locations: the areolae and the transition from cotyledonary to intercotyledonary chorion (marginal folds). Areolae were apparent in all samples examined and were generally filled with large amounts of secretory material and cellular debris. Due to the lack of a caruncular stalk marginal folds were poorly developed.

\section{Discussion}

Considerable parallels exist in uterine gross anatomy between $B$. taurus, $B$. bubalis [15] and S. caffer (this study). Caruncular arrangement in S. caffer in two mesometrial and two antimesometrial rows along most parts of the uterine horns and orientation of ovoid caruncles of the non-pregnant uterus in parallel to the longitudinal axis of the uterine horns are in accordance with descriptions in B. taurus [9] and [16] and B. bubalis [17]. In contrast, in the pregnant $S$. caffer uterus, ovoid placentomes are orientated perpendicular to the longitudinal axis of the horns, characteristic of a polycotyledonary type placenta [9]. In an oligocotyledonary type of placenta (e.g. deer species), placentomes remain longitudinally orientated throughout gestation [9]. The intrauterine development of a large bovine calf when compared to a relatively smaller fawn in deer species, involves an 
immense increase in uterine horn diameter and circumference. This may lead to the observed physical enlargement of placentomes parallel to the circumference of the uterine horns in bovine species.

The morphological features of the endometrium of the African buffalo are generally similar to those reported in cattle and water buffalo [18], [19], [20], [21] and [22]. The large variation in number and distribution of ciliated cells in the two buffalo cows examined is not surprising as the relative proportions of ciliated cells are reported to vary from $1 \%$ [21] to $20 \%$ [19] in the uterine surface epithelium of cattle. "Light cells", which are recognized as the ciliated cells in the $B$. taurus uterine epithelium [20], were observed by TEM in the intercaruncular epithelium of both buffaloes. Although cilia were seldom seen in TEM sections, basal bodies in the apical cell cytoplasm proved their existence. The occurrence of greater numbers of ciliated cells within the glandular epithelium compared to the surface epithelium has been reported in cattle [20].

In the $S$. caffer endometrium the prevalence of glandular tissues in the sub-caruncular lamina propria is striking. Endometrial caruncles are generally described as "gland-free endometrial tissue" in B. taurus, and endometrial glands occur much deeper, if at all, beneath the caruncular tissue proper in cattle [23]. In addition, the diameter of glandular profiles and glandular epithelial height in the non-pregnant buffalo endometrium are smaller than those reported in cattle [24]. However, the occurrence of larger glandular profiles with a higher epithelium in the more superficial region of the lamina propria follows the same pattern described in B. taurus [24].

The number of intraepithelial lymphocytes appears higher in the buffalo than in cattle endometrium [25]. Skjerven [26] describes "small well demarcated foci of lymphatic tissue" as physiologic in reproductively normal cattle. Although all buffaloes used in this study tested serologically positive for tuberculosis, no animal showed signs of clinical manifestation of the disease. Besides, the buffalo organs were free of pathological lesions, and the meat was therefore released for human consumption. The occasional accumulations of lymphocytes within the lamina propria, as observed in this study, may therefore indicate normal immunological activity required to maintain a healthy uterine environment.

The ridges and depressions observed on the caruncular surface of both non-pregnant buffalo uteri appear to result from endometrial folding. The cause and role of this phenomenon remain unclear. However, as both uteri originate from buffalo cows, not heifers, ridge formation might be related to a previous pregnancy. Morphological differences in the appearance of these ridges between the two uteri may be due to various levels of uterine involution and post-partum endometrial repair processes. The ridges may, however, also represent fixation artefacts.

No attempt was made to determine the stage of the cycle in the non-pregnant buffalo because of the small sample size. Cyclic changes in the $S$. caffer endometrium may be similar to those described in B. taurus, considering their similar uterine histo-morphology and length of the estrous cycle (range 18-22 days) [1] and [4]. However, detailed studies 
of endometrial changes during the estrous cycle in sufficient numbers of animals are advocated in order to obtain adequate data and information on reproductive processes in the African buffalo.

Results from the present study reveal evidence for a multicotyledonary, synepitheliochorial type of placenta in the African buffalo, similar to that of cattle and water buffalo [5], [27] and [28]. However, placentomes in the African buffalo placenta during all stages examined are clearly distinguishable from placentomes in cattle due to the lack of a caruncular stalk. In cattle, stalk formation regularly occurs from a fetal CRL of $9 \mathrm{~cm}$ onwards and includes all placentomes at the end of gestation [29] and [30]. During the period of stalk formation, Björkmann [29] reports the disappearance of the dense cellular layer in the cattle placentome, which is in agreement with the present study. In contrast, this prominent cell layer remains clearly visible in S. caffer placentomes at a similar CRL, and possibly plays a role in the lack of stalk formation. The B. bubalis placenta appears to be similar to the $S$. caffer placenta with regard to placentome shape since this species also exhibits non-pedunculated placentomes or placentomes with an indistinct, broad stalk throughout gestation [17] and [28]. Although there exists a possibility of further morphological changes in S. caffer placentomes during the remainder of pregnancy, the general placentome shape described in this study seems to persist until term. This is supported by personal investigations (Schmidt et al., unpublished data) and observations by Benirschke [5], who reports that cotyledons are flatter in delivered fetal membranes (afterbirths) of S. caffer than those described in comparable B. taurus specimens. Furthermore, another indicator for the lack of stalk formation during ongoing gestation might be the occurrence of endometrial glandular profiles close to the caruncular surface of cycling buffalo when compared to their restriction to deeper layers or their absence beneath cattle caruncles and placentomes [23].

To allow for a comparison between villous-crypt architecture of $S$. caffer and B. taurus placentomes in correlation to the size of the fetus, only most developed placentomes from the periembryonic regions were investigated. Fetal villi of cattle, measured at the centre of pedunculated placentomes, were up to four times wider than in the African buffalo whereas the width of villous tips was similar in both genera. Villous trees in cattle therefore adopt a triangular shape which has been described as representing a broad "Thuja-tree" during early gestation [31] and a Christmas tree during midgestation [10] and [32]. In contrast, the villous trees of early $S$. caffer placentomes are best described as a "Tuscany-cypress" in appearance due to their slender form and rudimentary branching, rather resembling villi described in B. bubalis [8] and [27]. It has been noted that during late gestation in cattle, tall-conical-shaped villous trees allow a denser arrangement of villi within a single placentome, which results in the maximal functional surface area of villous tissue in a given space [32]. In the African buffalo placenta, the simple yet dense villous arrangement during early gestation may compensate for the distinctly less developed villous branching when compared to that of cattle at similar fetal developmental stages. The concentration and close apposition of chorionic villi in the $S$. caffer and $B$. bubalis placenta may also be instrumental in the partial lack of meaningful secondary branching (smooth villous type) in these species [8]. 
One consistent feature in ruminant placentas is the TGC population within the chorionic trophoblast in all ruminants so far examined [33]. TGC have been studied extensively in various species [33], but, to date, have only been described in the trophoblast epithelium of African buffalo fetal membranes after delivery [5]. In the present study, histological and ultrastructural features of TGC emphasized the probable similarity in distribution, life span and function (the maternally directed transport of mediators across the placental barrier and their release in the maternal compartment [33]), between TGC of B. taurus and $S$. caffer. Evidence for multinucleated ( $>2$ nuclei) trophoblast cells, as demonstrated by Klisch et al. [34] in cattle, could not be substantiated in the present study. However, as serial sections were not examined, it is possible that cells containing more than two nuclei remained undetected. Moreover, "double lamellar bodies" (DLB), mentioned to be characteristic for ruminant TGC [33], were never found in TGC of the African buffalo.

In S. caffer, the presence of moderate numbers of crypt cells containing more than three nuclei is rather unusual, and the exact origin and function of these cells remain unclear. Multinucleate cells (MNC) within degenerating crypt epithelium are also described in the placentome of $B$. bubalis at mid-pregnancy [28], but the author does not give information on the number of nuclei per cell. In contrast to the uterine epithelium in sheep and goats [12] and [33], which consists to a large extent of multinucleate, feto-maternal syncytia throughout gestation, the bovine syncytia within the uterine epithelium are reported to contain three nuclei only, as a result of the fusion of a TGC with a single CEC [12]. However, an exclusive maternal origin for MNC, as suggested by Björkmann [29], seems unlikely, and a continuous fusion of TGC with feto-maternal hybrid cells, as described for sheep and goat [12] may be suggested for the African buffalo.

The disappearance of lymphocytes from the caruncular epithelium of pregnant $S$. caffer is in accord with other observations reported for B. taurus [35]. However, the increase in number of a specific population of lymphocytes in the interplacentomal areas described in the same study [35] could not be confirmed in the buffalo. Rather, a reduction in numbers or even absence of migrating cells seemed to occur in interplacentomal S. caffer epithelium. This phenomenon might reflect maternal immunological acceptance, necessary to allow the development of an allogeneic fetus within its mother's uterus. In many mammals, tolerance of the fetal allograft appears to involve the absence of expression of Major Histocompatibility Antigens (MHC) on the trophoblast cells, as well as the maintenance of an immunologically quiescent or immunosuppressive state of the uterus. In the bovine, the conceptus-maternal interface is rich in molecules that can inhibit maternal immune responses and the placenta itself is often referred to as an immunosuppressant environment [36]. Similar mechanisms can be expected to occur in S. caffer and the formation of feto-maternal hybrid tissue (MNC) and consequent continuous delivery of fetal signals by exocytosis, common to all ruminants, may be the basis for controlling the maternal immune response [12].

Interdigitating microvilli represent the final and most intimate feto-maternal contact in epitheliochorial type placentas. However, whereas a temporary lack of microvilli on the trophoblast surface commonly occurs during implantation in cattle [37], low numbers or a complete lack of microvilli on parts of the maternal surface epithelium observed during 
early stages of placentation in S. caffer are not in agreement with observations in cattle. Instances where a partial lack of microvilli occurs on the fetal, maternal or both sides of the placenta are reported in the camel (Camelus dromedarius) and a consequently slower establishment of the feto-maternal contact is suggested [38]. Although abundant microvilli are present on the endometrial epithelium of non-pregnant $S$. caffer, a partial loss of microvilli during early gestation may reflect a temporary situation resulting from a high maternal cell turnover [29] and could therefore also be related to a slower formation of feto-maternal contact. Besides this delay in feto-maternal contact, the morphological design (non-stalked, less complex villous-crypt architecture) of buffalo placentomes ( $S$. caffer and B. bubalis [17]) may result in a less efficient nutritional supply to the fetus and might partly explain the prolonged gestation period in these species. The lack of stalk formation in buffalo placentomes involves the reduction of an important structure generally present in the cattle placenta, the marginal folds [39]. These folds of chorioallantois, covered by columnar, phagocytic trophoblast epithelial cells, actively take up the secretions of endometrial glands around the base of the caruncular stalk and play an important role in the epitheliochorial placenta type supplying fetal histiotrophic nutrition by endometrial glands [39] and [40]. High endometrial gland activity in the pregnant $S$. caffer is apparent as glandular diameter as well as glandular epithelial height is greater in the pregnant than in the non-pregnant state. Furthermore, numerous small infoldings within the basal cytoplasm of glandular epithelial cells have been demonstrated in the present study. These infolds resemble features found in cells of the renal proximal tubular epithelium where they have been identified as multiple lateral processes which interdigitate with one another to form a complex baso-lateral intercellular space [41]. The greatly enlarged area of baso-lateral plasma membrane would increase space available for substance exchange, and may therefore enhance the functional capacity of endometrial glands, necessary to compensate for the reduced absorptive surface area of marginal folds in the buffalo. To our knowledge, this is the first description of baso-lateral infolds within endometrial glandular epithelial cells.

The present study is the first morphological description of the uterus and early placenta of the African buffalo. Although descriptions of the placenta and placentomes during later gestational stages in the African buffalo have not been reported, it appears that placental morphology in the two buffalo species, S. caffer and B. bubalis, may be more closely related than to that of cattle. This morphological similarity indicates a closer phylogenetic relationship between the two buffalo species, as suggested by craniological and recent molecular studies [2] and [3]. The knowledge gained from this study forms a basis for further research in reproduction, including assisted reproductive technologies, in the African buffalo.

\section{References}

[1] In: E.S.E. Hafez and B. Hafez, Editors, Reproduction in farm animals, Lippincott Williams and Wilkins, Philadelphia (2000), p. p. 509. 
[2] C.P. Groves, Systematic relationships in the bovini (Artiodactyla, Bovidae), Z Zool Syst Evolutionsforsch 19 (1981), pp. 264-278.

[3] J.B. Buntjer, M. Otsen, I.J. Nijman, M.T.R. Kuiper and J.A. Lenstra, Phylogeny of bovine species based on AFLP fingerprinting, Heredity 88 (2002), pp. 46-51.

[4] C. Knechtel, Brunstverhalten beim Kaffernbüffel (Syncerus caffer caffer) im Tierpark Berlin Friedrichsfelde, Zool Gart 63 (1993), pp. 32-58.

[5] K. Benirschke, Comparative placentation $<$ http://medicine.ucsd.edu/cpa/ $>$ (2005).

[6] D. Hufana-Duran, P.B. Pedro, H.V. Venturina, R.D. Hufana, A.L. Salazar and P.G. Duran et al., Post-warming hatching and birth of live calves following transfer of in vitroderived vitrified water buffalo (Bubalus bubalis) embryos, Theriogenology 61 (2004), pp. $1429-1439$.

[7] G.H. Arthur, D.E. Noakes, H. Pearson and T.J. Parkinson, Veterinary reproduction and obstetrics, Saunders, London (1996) p. 726.

[8] M.M.M. Abd-Elnaeim, M.A. Miglino, C. Pfarrer and R. Leiser, Microvascular architecture of the fetal cotyledons in water buffaloes (Bubalus bubalis) during different stages of pregnancy, Ann Anat 185 (2003), pp. 325-334.

[9] A. Andresen, Die Plazentome der Wiederkäuer, Morphol Jahrbuch 57 (1927), pp. $410-485$.

[10] R. Leiser, C. Pfarrer, M.M.M. Abd-Elnaeim and V. Dantzer, Feto-maternal anchorage in epitheliochorial and endotheliochorial placental types studied by histology and microvascular corrosion casts, Trophoblast Res 12 (1998), pp. 21-39.

[11] R. Leiser and P. Kaufmann, Placental structure in a comparative aspect, Exp Clin Endocrinol 102 (1994), pp. 122-134.

[12] F.B.P. Wooding, Current topic: the synepitheliochorial placenta of ruminants: binucleate cell fusion and hormone production, Placenta 13 (1992), pp. 101-113.

[13] A. Boos, V. Janssen and C. Mülling, Proliferation and apoptosis in bovine placentomes during pregnancy and around induced and spontaneous parturition as well as in cows retaining the fetal membranes, Reproduction 126 (2003), pp. 469-488.

[14] Schmidt S, Aire TA, Soley JT, Irons P, Cooper D, Gerber D. Fixation of the uterus and foeto-maternal unit of the African buffalo (Syncerus caffer) by glutaraldehyde perfusion under field conditions for histological and ultrastructural evaluation. Abstracts of the 15th international congress on animal reproduction, Porto Seguro; 2004. p. 7. 
[15] H. Dobson and M. Kamonpatana, A review of female cattle reproduction with special reference to a comparison between buffaloes, cows and zebu, J Reprod Fertil 77 (1986), pp. 1-36.

[16] B.A. Atkinson, G.J. King and E.C. Amoroso, Development of the caruncular and intercaruncular regions in the bovine endometrium, Biol Reprod 30 (1984), pp. 763-774.

[17] M. Abdel-Raouf and H.M. Bawadi, Morphological study of the uterine caruncles in Egyptian buffalo cows, Zentralbl Veterinarmed [A] (1966), pp. 252-263.

[18] E.M. Mokhless, M.M. Youssef and R.M. Khattab, Anatomy and histology of the reproductive organs of repeat breeder buffalo heifers, Annals Agric Sci Moshtohor 33 (1995), pp. 1275-1290.

[19] Y. Kojima and U. Selander, Fine structure of bovine surface endometrial cells in the estrous and luteal phase, Z Zellforsch Mikrosk Anat 104b (1970), pp. 557-571.

[20] T. Tsangaris, Elektronenmikroskopisches Bild des Endometriums beim Rind unter Berücksichtigung des Sexualzyklus, Zentralbl Veterinarmed [A] 18 (1971), pp. 842-866.

[21] U. Marinov and E. Lovell, Cytology of the bovine uterine epithelium during the estrous cycle, Am J Vet Res 29 (1968), pp. 13-30.

[22] A.W. Stinson, A.F. Weber and R. Zemjanis, The bovine endometrium - an electron microscopic study, Am J Vet Res 23 (1962), pp. 1164-1181.

[23] J. Priedkalns, Female reproductive system. In: H.D. Dellmann, Editor, Textbook of veterinary histology, Lea \& Febiger, Philadelphia (1993), pp. 233-254.

[24] Boos A. Histomorphologische Veränderungen im Endometrium des Rindes während der verschiedenen Zyklusphasen. PhD thesis, University of Hannover; 1981.

[25] A.L. Vander Wielen and G.J. King, Intraepithelial lymphocytes in the bovine uterus during the oestrous cycle and early gestation, J Reprod Fertil 70 (1984), pp. 457-462.

[26] O. Skjerven, Endometrial biopsy studies in reproductively normal cattle; clinical, histochemical and histological observations during the estrous cycle, Acta Endocrinol 22 (1956), pp. 87-101.

[27] R.D. Sharma, B.S. Nanda, R.P. Saigal, G.S. Khatra and S.K. Gupta, Histomorphological and histochemical studies of placentome and expelled foetal membranes of buffalo (Bubalus bubalis), Indian J Anim Sci 53 (1983), pp. 964-967.

[28] E.L.E. Yap, The placentome of the Philippine carabao (Bubalus bubalis) in midpregnancy: a study to establish the basis of clinic-pathological analysis on the possible causes of early reproductive failures, Philipp J Vet Med 13 (1974), pp. 1-17. 
[29] N.H. Björkmann, Morphological and histochemical studies on the bovine placenta, Acta Anat Suppl 22 (1954), pp. 1-91.

[30] R.A. Laven and A.R. Peters, Gross morphometry of the bovine placentome during gestation, Reprod Domest Anim 36 (2001), pp. 289-296.

[31] Ebert B. Die Mikrovaskularisation des Rinderplazentoms; Eine rasterelektronenmikroskopische Studie an Gefäßausgüssen im histologischen Vergleich. $\mathrm{PhD}$ thesis, University of Giessen; 1993.

[32] R. Leiser, C. Krebs, K. Klisch, B. Ebert, V. Dantzer and G. Schuler et al., Fetal villosity and microvasculature of the bovine placentome in the second half of gestation, $J$ Anat 191 (1997), pp. 517-527.

[33] F.B.P. Wooding and A.P.F. Flint, Placentation. In: G.E. Lamming, Editor, Marshall's physiology of reproduction, Chapman and Hall, London (1994), pp. 233-460.

[34] K. Klisch, C. Pfarrer, G. Schuler, B. Hoffmann and R. Leiser, Tripolar acytokinetic mitosis and formation of feto-maternal syncytia in the bovine placentome: different modes of the generation of multinuclear cells, Anat Embryol 200 (1999), pp. 229-237.

[35] C.S. Lee, F.B.P. Wooding and G. Morgan, Quantitative analysis throughout pregnancy of intraepithelial large granular and non-granular lymphocyte distributions in the synepitheliochorial placenta of the cow, Placenta 18 (1997), pp. 675-681.

[36] P.J. Hansen, Interactions between the immune system and the ruminant conceptus, $J$ Reprod Fertil Suppl 49 (1995), pp. 69-82.

[37] R. Leiser, Kontaktaufnahme zwischen Trophoblast und Uterusepithel während der frühen Implantation beim Rind, Anat Histol Embryol 4 (1975), pp. 63-86.

[38] M.M.M. Abd-Elnaeim, C. Pfarrer, A.S. Saber, A. Abou-Elmagd, C.J.P. Jones and R. Leiser, Fetomaternal attachment and anchorage in the early diffuse epitheliochorial placenta of the camel (Camelus dromedarius), Cells Tissues Organs 164 (1999), pp. 141154.

[39] H.W. Mossman, Vertebrate fetal membranes, Rutgers University Press, New Jersey (1987) p. 383.

[40] P. Vogel, The current molecular phylogeny of eutherian mammals challenges previous interpretations of placental evolution, Placenta 8-9 (2005), pp. 591-596.

[41] B. Young and J.W. Heath, Wheater's functional histology - a text and colour atlas, Churchill Livingston, Edinburgh (2000) p. 413. 